\title{
ON THE FINDS OF METAL CROSSES AT THE MEDIEVAL BURIAL GROUND OF GORZUVITY (THE SOUTHERN COAST OF CRIMEA)
}

\author{
Anna V. Mastykova \\ Institute of Archaeology of the Russian Academy of Sciences, Moscow, Russian Federation
}

\begin{abstract}
Introduction. In 2018, the Institute of Archaeology of the Russian Academy of Sciences conducted excavations of a burial ground (Artek, Gurzuf, Yalta district). The first researcher of this monument was A.L. Jacobson, and he discovered ten inventory-free graves. In 2018, more than twenty graves both with funeral inventory and non-inventory ones were discovered at the burial ground. Analysis and Results. Among the archaeological material, metal crosses from grave 7A deserve special attention. One is a bronze breast cross with a circular decor, the second one is an iron cross with a curved, elongated lower branch. The wire earrings, small metal bells-buttons, small glass beads found in the grave are known at many archaeological sites in a wide time range. Fragments of tiles from the burial belong to technological groups $1,2,4$ that can be dated from the $8^{\text {th }}$ to the $12^{\text {th }}\left(13^{\text {th }}\right.$ ? centuries. The search for analogies and the comparative analysis make it impossible to unambiguously determine the time of the bronze cross. It can be dated only in a wide chronological range - the $6^{\text {th }}-11^{\text {th }}$ centuries, not excluding the $12^{\text {th }}$ century, the iron cross most likely dates to the $9^{\text {th }}-10^{\text {th }}$ centuries. In the aggregate of items, burial $7 \mathrm{~A}$ can be tentatively dated broadly from the $8^{\text {th }}$ century to the $11^{\text {th }}$ century. Perhaps, using natural science methods that are currently being conducted, we will be able to clarify the date of burial 7A. The particular interest of the considered subjects of the Christian cult lies precisely in their ordinary and standard nature; they demonstrate the uniformization of the Byzantine material culture in the very wide territory from Egypt to Crimea. The burial ground of Gorzuvity demonstrates the byzantinization of the local barbarian population both in the material culture and in the burial rite. The finds of crosses in burial 7A fit well into the Byzantine context and are another clear confirmation of the evolution and chronology of the spread of Christianity in Crimea.
\end{abstract}

Key words: Byzantium, Southern Coast of Crimea, burial ground, objects of Christian cult, breast crosses, procession crosses.

Citation. Mastykova A.V. On the Finds of Metal Crosses at the Medieval Burial Ground of Gorzuvity (The Southern Coast of Crimea). Vestnik Volgogradskogo gosudarstvennogo universiteta. Seriya 4. Istoriya. Regionovedenie. Mezhdunarodnye otnosheniya [Science Journal of Volgograd State University. History. Area Studies. International Relations], 2019, vol. 24, no. 6, pp. 64-80. (in Russian). DOI: https://doi.org/10.15688/jvolsu4.2019.6.5

УДК 902(653)(470+571):726

Дата поступления статьи: 30.06.2019

ББК 63.444(2)-427 Дата принятия статьи: 09.09.2019

\section{О НАХОДКАХ МЕТАЛЛИЧЕСКИХ КРЕСТОВ НА СРЕДНЕВЕКОВОМ МОГИЛЬНИКЕ ГОРЗУВИТЫ (ЮЖНЫЙ БЕРЕГ КРЫМА)}

\author{
Анна Владимировна Мастыкова \\ Институт археологии РАН, г. Москва, Российская Федерации
}

Аннотация. В 2018 г. Институтом археологии РАН проводились раскопки грунтового могильника («Артек», Гурзуф, Ялтинский округ). Первым исследователем этого памятника был А.Л. Якобсон, он открыл десять безынвентарных захоронений. В 2018 г. на могильнике выявлено более двадцати могил как с погре- 
бальным инвентарем, так и безынвентарных. Среди археологического материала особого внимания заслуживают металлические кресты из погребения 7А. Один - бронзовый нагрудный крест с циркульным декором, второй - железный крест с загнутой, удлиненной нижней ветвью. Найденные в могиле проволочные серьги, небольшие металлические бубенчики-пуговки, стеклянные мелкие бусы известны на многих памятниках в широком временном диапазоне. Фрагменты керамид из погребения относятся к 1-й, 2-й, 4-й технологическим группам, которые могут быть датированы от VIII до XII (XIII?) века. Поиск аналогий и проведенный сравнительный анализ не дает возможности однозначно определить время бытования бронзового креста, его можно датировать лишь в широком хронологическом диапазоне - VI-XI вв., не исключая XII в., железный крест относится, скорее всего, к IX-X векам. По совокупности предметов погребение 7А предварительно можно датировать достаточно широко - от VIII до XI века. Возможно, с помощью естественнонаучных методов, которые проводятся в настоящее время, мы сможем уточнить дату погребения 7А. Особый интерес рассмотренных предметов христианского культа заключается именно в их ординарности и стандартности, они показывают униформизацию византийской материальной культуры на очень широкой территории от Египта до Крыма. Могильник Горзувиты демонстрирует византинизацию местного варварского населения как в материальной культуре, так и в погребальном обряде. Находки крестов в погребении 7А хорошо вписываются в византийский контекст и являются еще одним ярким подтверждением эволюции и хронологии распространения христианства в Крыму.

Ключевые слова: Византия, Южный берег Крыма, могильник, предметы христианского культа, нательные кресты, процессионные кресты.

Цитирование. Мастыкова А. В. О находках металлических крестов на средневековом могильнике Горзувиты (Южный берег Крыма) // Вестник Волгоградского государственного университета. Серия 4, История. Регионоведение. Международные отношения. - 2019. - Т. 24, № 6. - С. 64-80. - DOI: https://doi.org/10.15688/ jvolsu4.2019.6.5

Введение. В 2018 г. Гурзуфским отрядом Крымской новостроечной археологической экспедиции Института археологии РАН были начаты раскопки грунтового могильника, расположенного на территории МДЦ «Артек» (п. г. т. Гурзуф, Ялтинский округ) (рис. 1). Первым исследователем этого памятника был А.Л. Якобсон. В 1951 г. он открыл на этом участке остатки средневекового поселения, храмовую постройку («храм в храме») и к западу от храма - могильник [28; 29]. На могильнике им было исследовано десять захоронений, все они были безынвентарные.

В ходе полевого сезона 2018 г. на могильнике было выявлено более двадцати грунтовых захоронений как с погребальным инвентарем, так и безынвентарных. По погребальным конструкциям могилы относятся в основном к плитовым - перекрыты массивными каменными обработанными плитами; две могилы были перекрыты фрагментами черепицы и пифоса; одна - простая грунтовая могила без каменной конструкции. В целом погребения имеют подпрямоугольную в плане форму. У большинства могил погребальные конструкции нарушены, зачастую перекрывающие плиты треснуты, провалены внутрь могильного пространства. По всей видимости, это результат различных процессов: эрозионных, гравитационных (оползни, обвалы), сейсмических, которые достаточно активно проявлялись на данной территории. По этой же причине во многих захоронениях положение костяков зачастую нарушено и сдвинуто. В тех случаях, когда позиция костяков прослеживается in situ, можно констатировать, что умерших хоронили на спине в вытянутом положении со сложенными на тазу руками, головами на северо-запад / юго-запад или запад [17; 18$]$.

Среди археологического материала, обнаруженного при исследовании некрополя Горзувиты, особого внимания заслуживают предметы христианского культа - это металлические кресты [19]. В данной работе будут рассмотрены два креста из погребения 7А.

Методы. Для подробного изучения указанных предметов они будут представлены в археологическом контексте их обнаружения, будет дана подробная характеристика и атрибуция крестов, выявлен круг аналогий и проведен сравнительный анализ параллелей, что позволит определить время бытования изучаемых крестов.

Анализ. Некрополь Горзувиты располагался на отвесном склоне, местами его кру- 


\section{ВИЗАНТИЙСКАЯ ТАВРИКА}

тизна достигала $45^{\circ}$. Грунтовая могила № $7 \mathrm{~A}$ выявлена на западном участке некрополя, ее длина $-3,30$ м, ширина $-1,25$ м, средняя глубина от уровня выявления - 0,61 м. Погребение имеет подпрямоугольную в плане форму, своей длинной осью ориентирована на 3-В. По погребальной конструкции могила 7А относится к плитовым, но первоначальное положение перекрытия было нарушено, частично плиты разбиты и «ушли» вглубь могильного пространства (рис. 2). Как были оформлены стены могильной ямы, в целом определить сложно, но судя по сохранившимся участкам длинные стены были выложены массивными прямоугольной формы обработанными каменными блоками и мелкими камнями с фрагментами керамид.

После проведения антропологической экспертизы можно будет судить о количестве погребенных людей в этой могиле. На данный момент надо лишь констатировать, что проследить позицию погребенного (погребенных (?)) in situ не удалось, анатомический порядок костей (кости плохой сохранности) нарушен. Причем множественные фрагменты костей зафиксированы на всех трех уровнях зачистки, но не исключено, что все фрагментированные кости с этих уровней относятся к одному индивиду, так как они могли быть сдвинуты и «растянуты» на разную глубину из-за процессов, о которых говорилось выше (сейсмических, гравитационных и пр.).

В процессе работы было произведено три слоя фиксации. В слое I, на глубине $0,07-$ 0,09 м от уровня выявления могилы, были расчищены многочисленные фрагменты костей скелета человека. Находки в слое I: одиннадцать фрагментов керамид; две бронзовые ${ }^{1}$ серьги из круглой в сечении проволоки, концы которой сделаны в виде крючка и петельки, одна - застегнута, вторая - разомкнута; еще один фрагмент такой же серьги; в 0,10 м от западной стены могилы и 0,15 м от южной найден бронзовый крест, лежащий лицевой частью вниз.

После снятия 0,25-0,30 м слоя I - светло-коричневого суглинка с фрагментами костей и костного тлена, был расчищен слой II, в котором были зафиксированы незначительные фрагменты костяка. Находки в слое II: пять фрагментов керамид; в 1,48 м от западной могильной стены и 0,15 м от северной обнаружен железный крест, находившийся лицевой частью вверх.

Затем, после снятия 0,02-0,18 м слоя II светло-коричневого суглинка с фрагментированными костями и костным тленом, открылся следующий уровень - слой III, в котором также присутствовали фрагменты костей скелета. Находки в слое III: четыре фрагмента керамид; в центральной части могилы зафиксированы 29 экземпляров стеклянных мелких одноцветных бус; в 1,07 м от западного края могилы и 0,74 м от северного обнаружена бронзовая серьга из круглой в сечении проволоки с застегнутыми концами в виде крючка и петельки; в 0,10 м от серьги на восток - бронзовая пуговица-бубенчик.

В целом, как мы видим, погребальный инвентарь незначительный и не очень выразительный, наибольший интерес из найденных вещей в этой могиле, безусловно, представляют два металлических креста.

Бронзовый пластинчатый нагрудный крест с петелькой для подвешивания практически равноконечный, с равномерно расширяющимися концами; каждая ветвь украшена циркульной композицией - прочерченным кругом с точкой-углублением в центре него, а также верхняя ветвь - двумя горизонтальными линиями, нижняя - тремя; в средокрестии - две перекрещенные линии (рис. 3,1 ). Размеры: высота с петелькой - 4,4 см, высота без петельки $-3,7$ см, ширина $-2,4$ см.

Подобные нагрудные кресты известны в Крыму и на других памятниках. На ЭскиКермен (Юго-Западный Крым) два креста аналогичной формы с циркульным декором на концах и средокрестии, но меньших размеров $(2,6 \times 1,4 ; 2,6 \times 1,5$ см), были найдены в склепе 335/1982 г., и таких же три креста - в склепе $380 / 2013$ г. [26, с. $163 ; 27$, с. 280,281 , рис. 1 , $1,2 ; 2]$ (рис. 3, 6, 7). Они отнесены Э.А. Хайрединовой к типу 3-3, который датируется последней четвертью VI - первой половиной VII в. [26, с. 163 , рис. $1,23,26 ; 7,1,2]$. В могиле 133 некрополя Судак-II (Юго-Восточный Крым) бронзовый крест (около 3,3 × 1,61,7 см) с равномерно расширяющимися концами, три луча (один - обломан) и средокрестие которого украшены концентрическими кругами, обнаружен вместе с двустворчатым эн- 
колпионом, относящимся к киевской группе, датирующейся в рамках второй четверти XII - первой половины XIII в. (рис. 3, 5). Однако, по мнению В.В. Майко, не исключено, что это вторичное использование креста $[16$, c. $57,136,139$, рис. $83,8,9]$. Еще один крест, лучи которого также имеют подобный декор (около $4,1 \times 2,37 \mathrm{~cm}$ ), выявлен в могиле 142 этого же некрополя [16, с. 58, рис. 93, 11]. В коллекции Государственного Эрмитажа хранится крест-тельник $(3,1 \times 1,9$ см; Кат. № 236) аналогичной формы с декором в виде «врезанных кружков-гнезд», украшавший лучи и средокрестие. Он найден на Херсонесском городище внутри монастырской ограды (рис. 3, 2). У второго подобного крестика $(3,2 \times 2,2 \mathrm{~cm}$; Кат. № 238), из эрмитажной коллекции, на перекрестье и концах - концентрические кружки, но его происхождение неизвестно (рис. 3,3 ). Оба изделия отнесены к V-VII вв. [10, с. 129]. Еще три креста известны в «сирийской коллекции» Б.И. и В.Н. Ханенко (Национальный музей истории Украины). Один крест (3,23,6 × 2,4 см; Кат. № 59), лицевая сторона которого украшена циркульным декором, атрибутирован как византийский, VI-XI вв. (рис. 3,4$)$. Второй - большего размера $(6,8-$ 7,5 × 4,2 см; Кат. № 81), с циркульным орнаментом на ветвях и глубоким гнездом для вставки в средокрестие, отнесен к числу византийских, X-XI вв. (рис. 3,8 ). Наконец, третий крест $(3,45 \times 3,5$ см; Кат. № 82) декорирован с двух сторон ${ }^{2}$, лицевая сторона имеет циркульный орнамент и тройные ряды прямых линий (на горзувитском кресте - двойные линии), оборотная сторона украшена двумя и тремя прямыми параллельными линиями (рис. 3, 9). Он причислен к изделиям Балкано-Дунайского региона (?) и датирован $\mathrm{X}$ ХІ вв. [21, с. 153, 196, 197].

Нагрудные бронзовые кресты подобной формы, иногда с более широкими концами ветвей, их еще называют мальтийскими [38; 41, S. 199], с пятью циркульными композициями на ветвях и перекрестье, чрезвычайно широко распространены в Восточном Средиземноморье. По мнению некоторых исследователей, эти пять точек имитируют гвозди, которыми был прибит на кресте Христос [38, p. 423]. Нательный крест (около $3 \times 1,9$ см) был найден на раскопе 5 Иоасафовского уча- стка византийского Иерихона в Палестине (рис. 3, 10). Крестик, датированный VIVII вв., на лучах и перекрестье украшены пятью кругами с углублением в центре, которые, как отмечает Л.А. Беляев, считаются имитацией камней или эмалей [3, с. 293, рис. 256]. Известны такие изделия и на других палестинских памятниках, например в церкви в Бейт Анун (Beit Anun) [35, p. 184, fig. 12] и в церкви Анаб эль-Кабир ('Anabel-Kabir) [36, p. 380-381, pl. 6, № 7].

В Израиле на побережье Средиземного моря при раскопках Кесарии Приморской (Caesarea Maritima) был обнаружен фрагментированный крестик, два сохранившихся конца и средокрестие которого декорированы кругами с центральной точкой [38, p. 423, № 42].

В Северной Сирии на византийском памятнике Кал'ат-Сам'ан (Qal'at Sem'an) среди прочих находок также имеются два креста, украшенные пятью кругами с углублениями в центре (US 618: 2,7 × 1,6 см; US 606: $2,9 \times 1,7$ см). Они найдены вместе с монетой Ираклия 613-614 гг. на полу помещения (VS $02^{3}$ ) для приема паломников, расположенного на улице, ведущей к знаменитому монастырю Св. Симеона Столпника (рис. $3,11,12)^{4}$. Этот слой помещения Д. Пьери датирует 610650 гг. [39, p. 1414-1417, fig. 19].

В Турции, в храмовой могиле VI-VII вв. римского города Элеуса Себасте (Elaiussa Sebaste), в Киликии, найдены два креста подобной формы и декора [33, pl. 5, ill. 46, 47]. В музее турецкого города Кютахья находится подвеска, состоящая из серьги с литым многогранником, на которой висят четыре креста, три из которых украшены концентрическим декором [27, с. 281, рис. 1,3].

Аналогичные кресты известны в материковой Греции. В могиле 3 некрополя Азоpoc (Azoros), в местечке Палиоклиси (Paliokklisi / «Старая церковь») вблизи г. Элассона (префектура Лариса, регион Фессалия) ${ }^{5}$, был найден крест, декорированный пятью окружностями с центральной точкой $(2,8 \times 1,8 \mathrm{~cm})$, который был отнесен к средневизантийскому периоду [32, р. 406, № 510] (рис. 3, 13). В некрополе Верия (Veria) (префектура Пелла в Центральной Македонии) известен подобный крест $(3,4 \times 1,8$ см), найденный на груди погребенного ребенка, по контексту могилы и 
аналогиям из Коринфа датированный X-XI вв. [32, р. 500, № 684] (рис. 3, 14). А.А. Пескова и Л.В. Строкова отмечают, что аналогичные кресты с циркульным орнаментом имели достаточно широкое распространение в X-XI вв. в Греции и на Балканах (аналогии и библиографию см.: [21, с. 153]).

В коптской коллекции музея Лувра хранятся два креста, один $(2,8 \times 1,9$ см $)$ украшен пятью рельефными кружками, второй $(2,4 \times 1,6$ см) - прочерченными [31, p. 180, E 13554, E 13555].

Безусловно, список находок нагрудных крестов подобного типа, приведенный здесь, не является исчерпывающим, но даже по перечисленным аналогиям можно судить, что кресты с циркульными композициями пользовались особым спросом в Восточном Средиземноморье и распространялись на широкой территории от Египта до Крыма. К сожалению, не всегда они были найдены в закрытых комплексах, но в тех случаях, когда известен археологический контекст, чаще всего исследователи их датируют VI-VII веками. Однако учитывая некоторые находки (некрополь Верия и др.), по всей видимости, кресты такого типа могли бытовать и позже.

Стоит также отметить, что изображения крестов подобной формы с циркульным декором были очень популярны и использовались, например, в оформлении щитка пряжек или ручек металлических светильников и пр. [31, p. 18, Е 14283]. Крестовидные пряжки с циркульным декором известны в Крыму, в частности на могильнике Суук-Су (Южный берег Крыма) в земляном склепе 131 , с монетой боспорского царя Фофорса (279-308 гг.) явно вторичного использования. Сама могила, судя по погребальному инвентарю, относится к VII в. (рис. 4, 1). Здесь у погребенного мужчины на тазу лежали три пряжки, одна из них крестовидная с циркульным орнаментом [23, c. 111-112, рис. 108]. Еще одна такая пряжка была найдена на могильнике Эски-Кермен (Юго-Западный Крым), в склепе 257, в захоронении 1 второй половины VII в. [1, с. 188, рис. 10,8$]$ (рис. 4,2 ). Декорированные кружками пряжки в виде мальтийского креста больше всего представлены в Восточном Средиземноморье: в Малой Азии (рис. 4, 3); в «Византии» (рис. 4, 4); в Ахмим-Панополисе
(Achmîm-Panopolis) в Египте (рис. 4, 5), в Библосе (Byblos) в Ливане, Цариграде (Carigrad) в Иллирикуме, в Ст. Мауро Сотто (St. Mauro Sotto) в Сицилии, в Дибси-Фарадже (DibsiFaraj) в Сирии [41, S. 199, 200, № 189-191; 42, tab. XIX, 9; 37, p. 73, fig. 5; 34, fig. 2, 12]. По мнению М. Шульце-Дорламм, именно такой тип пряжек характерен для конца VI - первой половины VII в. [41, S. 200]. Эта дата крестовидных пряжек соответствует дате наибольшего распространения нагрудных крестов рассматриваемого типа.

Вернемся к рассматриваемому нагрудному кресту из горзувитского погребения 7А. Напомню, что в этой же могиле было обнаружено двадцать девять стеклянных мелких одноцветных бусин. Известно, что подобные кресты, как правило, носились в составе ожерелий. Подтверждением этому служат найденные в склепе 380/2013 г. на Эски-Кермен кресты вместе со стеклянными мелкими бусами, некоторые из которых застряли в петельках для подвешивания [27, с. 281, рис. 1,$2 ; 2$, $3 a, 36,4 a, 46]$ (рис. 3,7 ). Такие же случаи зафиксированы на могильнике Лучистое в склепах 100, 124, 268 второй половины VI первой половины VII в. [26, рис. 10, 2; 11, 1, 2]. Не исключено, что горзувитский крест тоже входил в состав бусинного ожерелья. По наблюдениям Э.А. Хайрединовой, кресты носили только женщины и дети, в ожерельях вместе с бусами [27, с. 287]. Учитывая погребальный инвентарь (серьги, бусы), можно допустить, что могила 7А в Горзувитах была женской, дальнейшие антропологические исследования, вероятно, смогут уточнить это предположение.

Поиск параллелей и проведенный сравнительный анализ горзувитского нагрудного креста, к сожалению, не дают возможности однозначно определить время его бытования. Выявленный круг аналогий показал, что подобного типа кресты более всего характерны для VI-VII вв., их размеры (там, где они указаны) варьируют от совсем небольших до более крупных экземпляров. В то же время фиксируются находки таких крестов в более позднем контексте могил - X-XII вв. вплоть до первой половины XIII в. (некрополи Азорос, Верия, Судак-II). Поэтому датировать нагрудный крест из горзувитского погребения 
можно лишь в широких хронологических рамках VI-XI вв., не исключая XII век.

Рассмотрим второй крест из погребения

7А на некрополе Горзувиты.

Железный пластинчатый крест с равномерно расширяющимися концами, с загнутой, удлиненной и заостренной нижней ветвью, возможно для фиксирования на какой-то деревянной конструкции ${ }^{6}$ (рис. 5,1 ). Размеры: высота с длинным концом - 7,4 см, высота без него - 6,2 см, ширина $-3,4$ см.

Прямые аналогии горзувитскому железному кресту имеются на двух крымских памятниках. На горе Пахкал-Кая (Южный Крым) при исследовании раннесредневекового храма IX/X-XIII/XIV вв. было найдено двенадцать железных крестов с заостренным крюком у основания, отнесенных к группе II $[14$, с. 298 , рис. $5,1-6]$ (рис. $5,3-5$ ). Они близки по форме и размеру $(6,1-7,3 \times 2,6-3,0$ см) экземпляру из Горзувит. Крюки, как отмечают исследователи, служили для крепления к деревянным деталям здания или между камнями кладок стен $[14$, с. 299]. Подавляющее большинство этих крестов происходит из слоя 26, что является свидетельством достаточно раннего появления их здесь и позволяет отнести эти находки к первому этапу функционирования средневекового храма, то есть к IX-X вв. [14, с. 305]. В материалах раскопок храма на холме Тузлух у с. Семидворье (Южный берег Крыма, Алушта) также имеется железный пластинчатый крест (размеры $2,65 \times 5,9$ см; № 210) с расширенными подтреугольной формы ветвями и заостренной нижней ветвью, который отнесен к I типологической группе крестов [20, с. 191, рис. 5.5, $210]$ (рис. 5, 2). Крест происходит из слоя № 4, соответствующего III строительному периоду, датированному 60-80 гг. IX - второй трети / середины Х в. [20, с. 191, 192, рис. 5.5, $210 ; 25$, с. 208 , табл. 1 , рис. 7,210$]$.

Похожие железные кресты, но с несколько иными морфологическими и технологическими характеристиками, с более длинной заостренной, иногда загнутой, нижней ветвью известны на других крымских памятниках. В Юго-Западном Крыму: на поселении VIIIIX вв. у с. Бобровки (Байдарская долина) [30, c. 81 , рис. 43,8$]$, в склепе 220 Эски-Кермен с погребальным инвентарем VII-IX вв. [26, c. 155 , рис. 2,8$]$, в склепе 771 второй половины VIII - IX в. в Скалистинском могильнике $[5$, с. $160,161,197,198$, рис. 121,8$]$. В ЮгоВосточном Крыму: на некрополе и усадьбе 2 Кордон-Оба [15, с. 249, рис. 140, 6, 8]; при раскопках дома 1 Тепсень-57 и в культурном слое возле храма 6 Тепсень- 98 [15, с. 249 , рис. 140 , $2,10]$. Находки таких железных крестов, но более крупных размеров известны на Северном Кавказе, где их называют крестами «византийско-кавказского типа» $[4 ; 11 ; 13]$. Они встречены на следующих памятниках: в храме XII в. на городище Верхний Джулат (Кировский район Северной Осетии) - клад из семи железных крестов разных форм и размеров, лежавших в развале глиняного сосуда $[11$, с. 53 , рис. $6,1,2]$; на городище Нижний Джулат (Майский район Кабардино-Балкарии) $[12$, рис. 22, 7]; на хуторе недалеко от Ильичевского городища и в церкви № 1 на этом же городище (Отрадненский район Краснодарского края) [13, с. 202, 203, рис. 1, 1, 3; 2, 2]; в фондах Краснодарского музея хранятся два креста, происходящие, вероятно, с территории Кубанской области $[4$, рис. $1,1,2]$; в византийском храме IX-X вв. у пос. Веселое (Адлеровский район Большого Сочи) [2, с. 83, 89, рис. 4,1$]$.

Считается, что железные кресты таких типов происходят от индивидуальных процессионных крестов византийского обряда, со временем эти кресты могли использоваться как вотивные приношения в храмах [13, с. $204 ; 24$, с. $246 ; 25$, с. 213-215]. В Крым традиция вотивных даров проникает, вероятно, с ромеями - переселенцами из Малой Азии [14, c. 299].

Приведенные прямые аналогии железному кресту из горзувитского погребения 7А позволяют предположить, что время их бытования, вероятнее всего, относится к IX$\mathrm{X}$ векам. Интересен сам факт появления в могиле креста с удлиненной, загнутой ветвью. Можно допустить, что этот крест был положен в могилу как вотивный дар, некогда крепившийся на какой-то деревянной конструкции. Или же, учитывая наличие «крюка», он мог быть закреплен на крышке гроба, следы которого не были зафиксированы в погребении, однако на удлиненной и загнутой ветви креста, как уже говорилось выше, сохранились 


\section{ВИЗАНТИЙСКАЯ ТАВРИКА}

следы дерева. Надо отметить, что на могильнике Горзувиты в 1951 г. была открыта одна грунтовая могила (№ 9) без каменной конструкции, погребение совершено в гробу, следы которого были видны. Эту могилу А.Л. Якобсон отнес к более раннему времени, поскольку она близка по типу к погребениям нижнего слоя могильника Суук-Су, то есть к VI-VII вв. [22, c. 30-35; 29, с. 116]. На Скалистинском могильнике в погребении второй половины VIII - IX в. склепа 771, о котором упоминалось выше, железный крест лежал на полу под деревянной колодой ладьевидной формы $[5$, с. 180,181$]$.

Результаты. Для понимания датировки захоронения 7А могильника Горзувиты проанализируем весь погребальный инвентарь. Найденные в могиле четыре (одна фрагментированная) проволочные серьги, стеклянные мелкие одноцветные бусы известны на многих памятниках в широком временном диапазоне. Небольшие металлические бубенчикипуговки, такие, как в горзувитском погребении, достаточно часто встречаются в крымских, северокавказских и балканских средневековых материалах. В могиле было обнаружено двадцать фрагментов керамид 1-й, 2-й и 4-й технологических групп ${ }^{7}$, которые, скорее всего, относятся к периоду от VIII до XII (XIII?) в. [7, с. $254 ; 8$, с. 218,$219 ; 9$, с. 307 , 308]. Бронзовый нагрудный крест отнесен к VI-XI вв., не исключая XII в., железный крест - к IX-X векам. Таким образом, по совокупности предметов погребение 7А пока предварительно можно датировать достаточно широко, скорее всего, в диапазоне от VIII до XI века. Возможно, с помощью естественнонаучных методов, которые проводятся в настоящее время, мы сможем не только получить сведения о количестве погребенных, но и уточнить дату погребения 7А.

Подводя итог, хотелось бы отметить, что особый интерес рассмотренных предметов христианского культа заключается именно в их ординарности и стандартности, поскольку они демонстрируют униформизацию византий- ской материальной культуры, в частности в том, что касается повседневных предметов христианского культа, на очень широкой территории от Египта до Крыма. Могильник Горзувиты демонстрирует византинизацию местного варварского населения как в материальной культуре, так и в погребальном обряде. Одно из проявлений этой религиозной интеграции известно из Прокопия Кесарийского готы страны Дори уже в середине VI в. христиане [40, III.VII.11]. Однако внешнее проявление христианства в материальной культуре более ярко фиксируется все-таки позднее. Находки крестов в погребении 7А некрополя Горзувиты хорошо вписываются в византийский контекст и являются еще одним ярким подтверждением эволюции и хронологии распространения христианства в Крыму.

\section{ПРИМЕЧАНИЯ}

1 Здесь и далее определение цветного металла дается визуально, химический состав изделия в настоящее время изучается.

2 Двухсторонний декор встречается на древнеболгарских нательных крестах, наиболее близкая аналогия кресту из сирийской коллекции происходит из крепости Скала на Нижнем Дунае в Болгарии (см.: [6, с. 202, 203, кат. № 786], цит. по: [21, с. 197]).

${ }^{3}$ Как уточнил М.М. Казанский (старший), занимавшийся изучением металлических предметов в момент раскопок 2009 г., кресты происходят из секторов 2 и 8 помещения VS 02.

${ }^{4}$ Благодарю руководителя раскопок Доминика Пьери за любезное разрешение опубликовать фотографии крестов из помещения VS 02.

5 Приношу свою благодарность М.М. Казанскому (младшему) за помощь в географической локализации греческих памятников.

${ }^{6}$ При реставрации этого креста на удлиненной загнутой ветви были обнаружены следы дерева.

7 Определение черепицы проводила И.А. Завадская (НИЦ истории и археологии Крыма Крымского федерального университета им. В.И. Вернадского). Пользуясь случаем, приношу ей искреннюю благодарность. 
A.B. Мастыкова. О находках металлических крестов на средневековом могильнике Горзувиты

\section{ПРИЛОЖЕНИЕ}

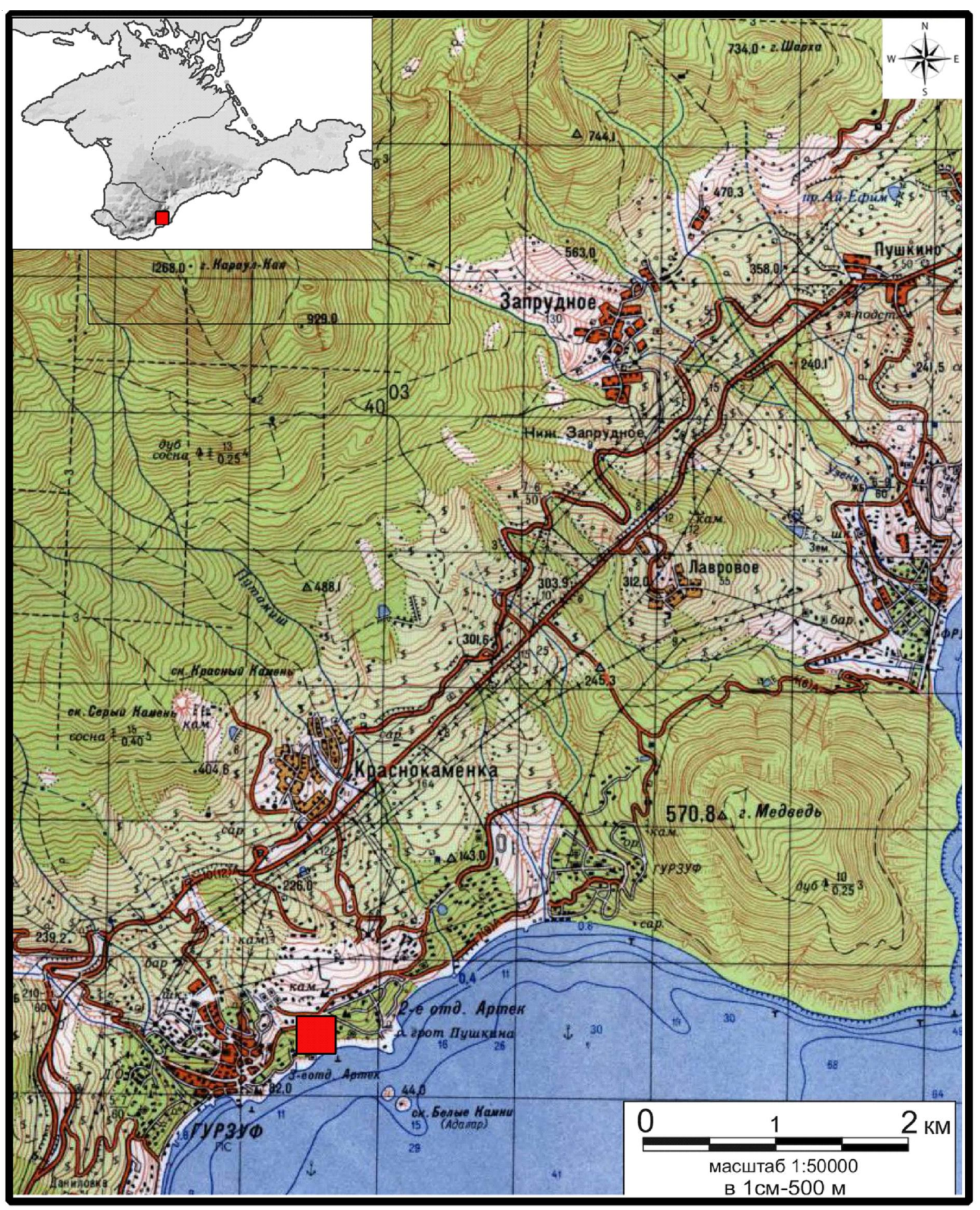

Рис. 1. Республика Крым. Ялтинский городской округ. Фрагмент карты ГШ-36, 1986 г. Квадратом обозначено местоположение памятника Горзувиты

Fig. 1. Republic of Crimea. Yalta city district. Fragment of the map ГШ-36, 1986. The square indicates the location of Gorzuvity monument 


\section{ВИЗАНТИЙСКАЯ ТАВРИКА}

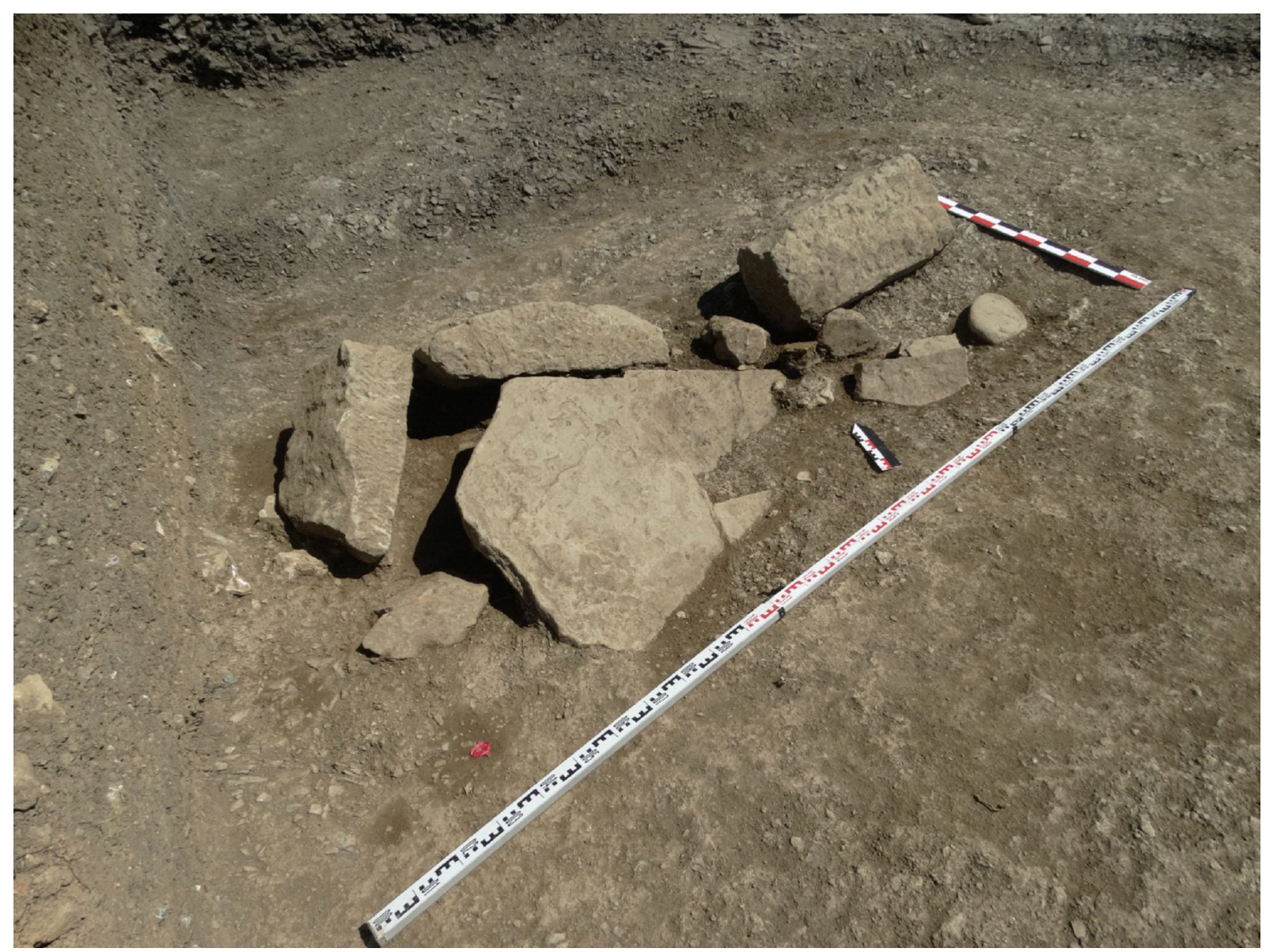

Рис. 2. Южный берег Крыма, могильник Горзувиты.

Погребение 7А, вид с юга-запада, уровень выявления

Fig. 2. The southern coast of Crimea, burial ground of Gorzuvity.

Burial 7A, view from the southwest, detection rate 

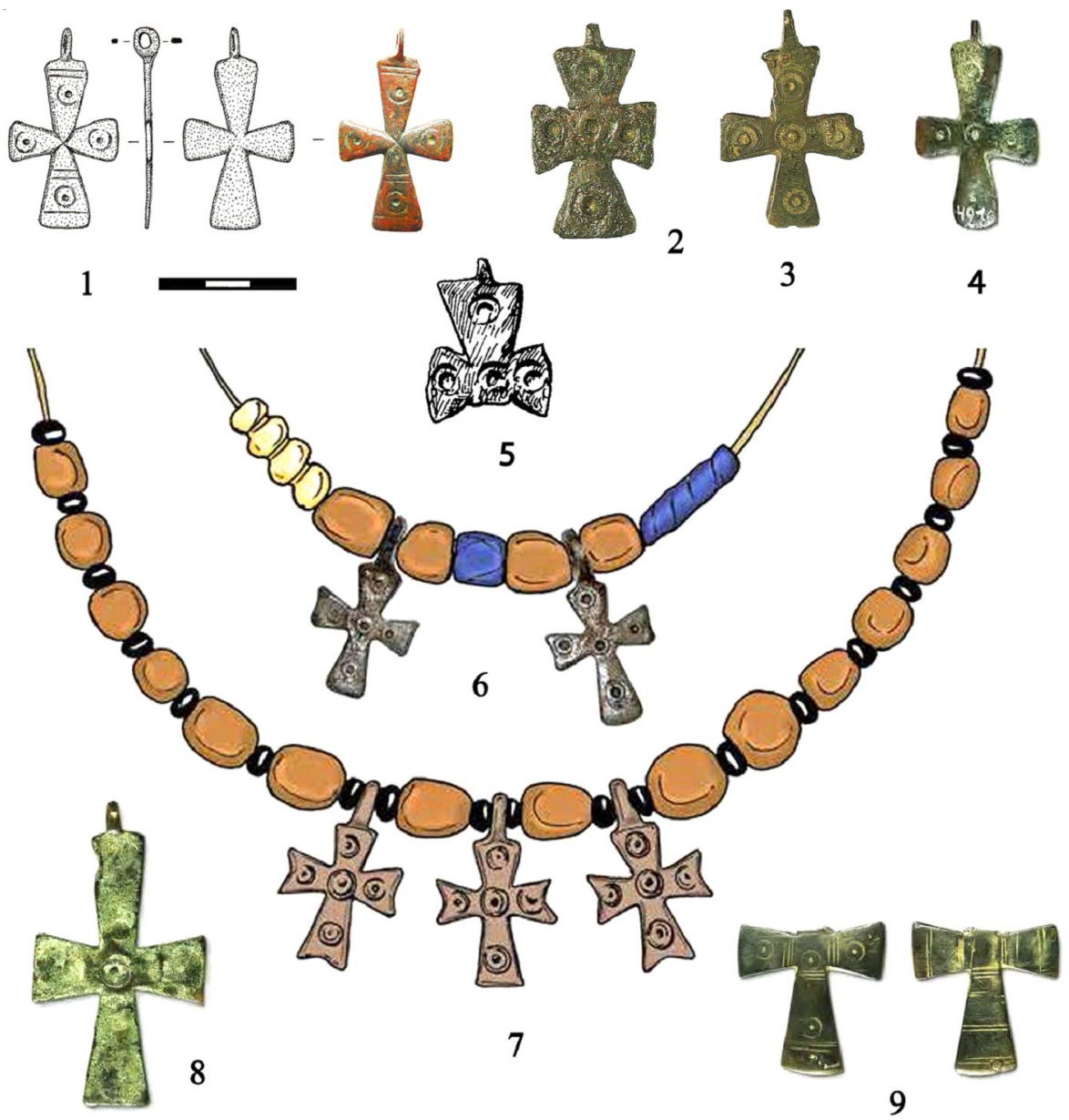

23

4
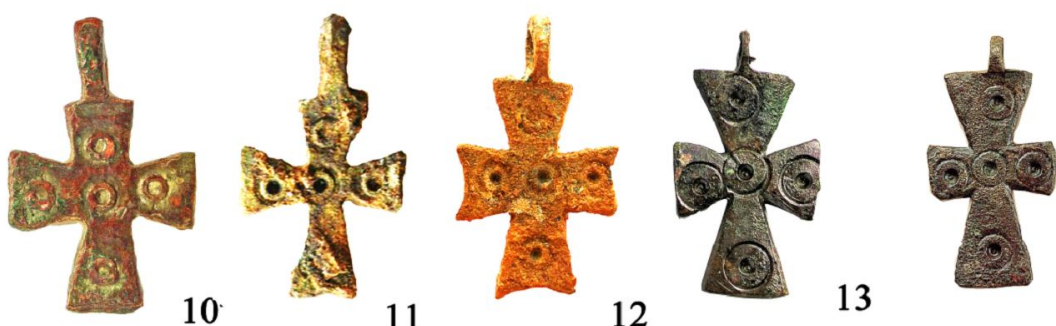

14

Рис. 3. Бронзовые нагрудные кресты с циркульным декором:

1 - Южный берег Крыма, могильник Горзувиты, погребение 7А (рисунок и фото С.Л. Богаченко); 2, 3 - коллекция Государственного Эрмитажа [10, кат. № 236, 238];

4, 8, 9 - «сирийская коллекция» Б.И. и В.Н. Ханенко, Национальный музей истории Украины [21, кат. № 59, 81, 82];

5 - Юго-Восточный Крым, погребение 133 могильника Судак-II [16, рис. 83, 8];

6, 7 - Юго-Западный Крым, Эски-Кермен (6 - склеп 335/1982 г.; 7 - склеп 380/2013 г.) [27, рис. 1, 1, 2]; 10 - Палестина, Иерихон, Иоасафовский участок, раскоп 5 [3, рис. 256];

11, 12 - Сирия, Кал'ат-Сам'ан (Qal'at Sem'an) (11 - US 618; 12 - US 606) (фото М.М. Казанского (старшего)); 13 - Греция, могила 3 некрополя Азорос (Azoros) [32, кат. № 510]; 14 - Греция, некрополь Верия (Veria) [32, кат. № 684]

Fig. 3. Bronze breast crosses with a circular decor:

1 - Southern coast of Crimea, burial ground of Gorzuvity, burial 7A (drawing and photo by S.L. Bogachenko); 2,3 - collection of the State Hermitage Museum [10, cat. no. 236, 238];

4, 8,9 - "Syrian collection" of B.I. and V.N. Khanenko, National Museum of the History of Ukraine [21, cat. no. 59, 81, 82]; 5 - Southeastern Crimea, burial 133 of Sudak-II burial ground [16, fig. 83, 8];

6, 7 - Southwestern Crimea, Eski-Kermen (6 - crypt 335/1982; 7 - crypt 380/2013) [27, fig. 1, 1, 2]; 10 - Palestine, Jericho, Joasaph site, excavation site 5 [3, fig. 256];

11,12 - Syria, Qal'at-Sam'an (11 - US 618; 12 - US 606) (photo by M.M. Kazanskiy (senior));

13 - Greece, grave 3 of the necropolis of Azoros [32, cat. no. 510]; 14 - Greece, the necropolis of Veria [32, cat. no. 684] 


\section{ВИЗАНТИЙСКАЯ ТАВРИКА}
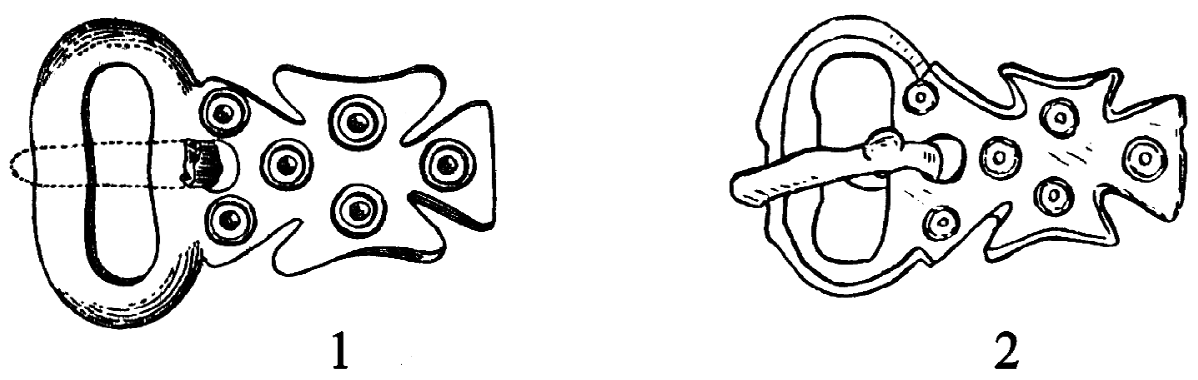

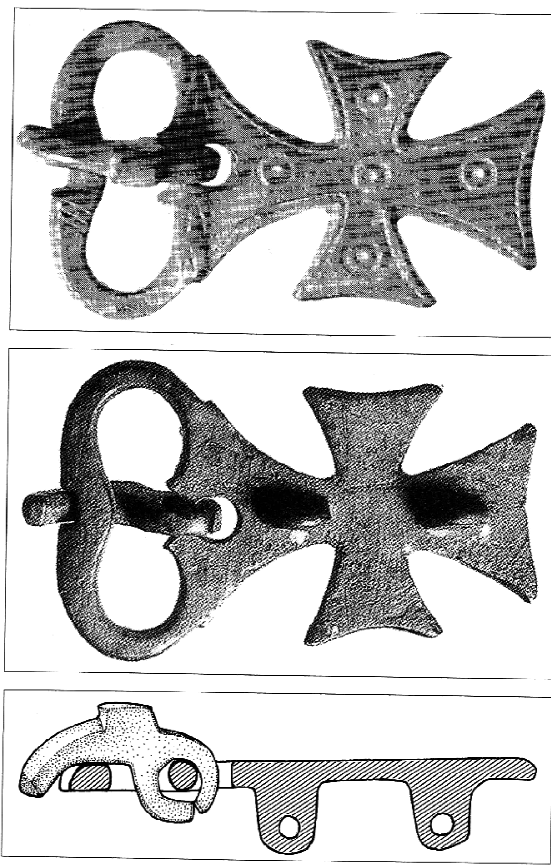

3
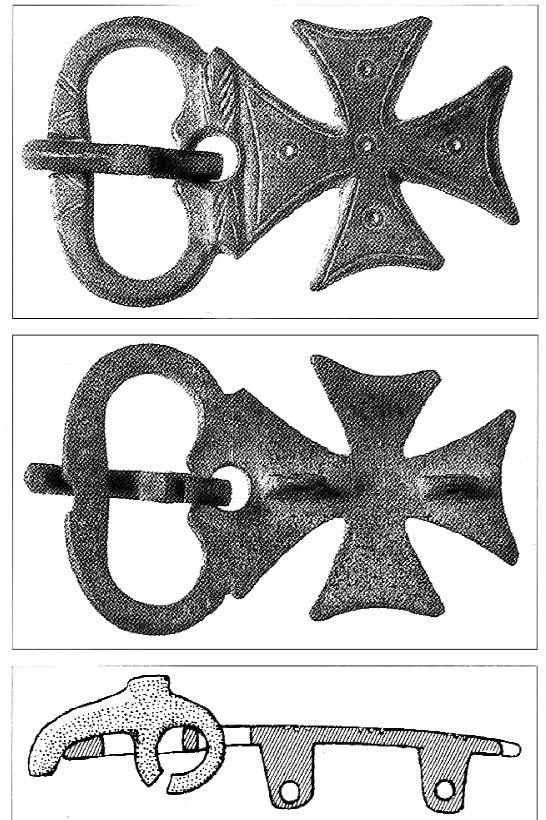

4
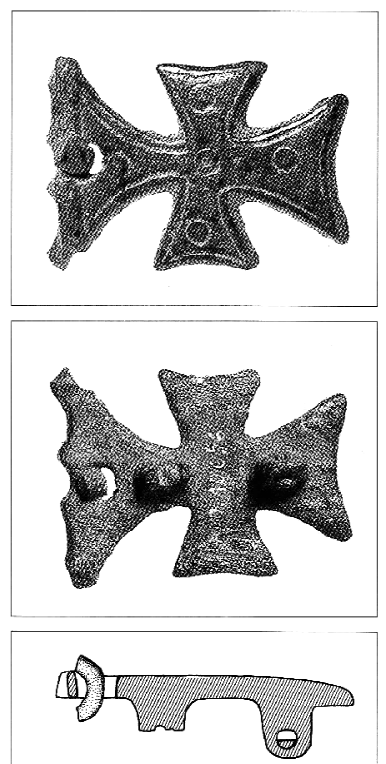

5

Рис. 4. Крестовидные пряжки с циркульным декором:

1 - Южный берег Крыма, склеп 131 могильника Суук-Су [23, рис. 108];

2 - Юго-Западный Крым, склеп 257, Эски-Кермен [1, рис. 10, 8]; 3 - Малая Азия [41, S. 199, № 189];

4 - «Византия» [41, S. 200, № 190]; 5 - Египет, Ахмим-Панополис (Achmîm-Panopolis) [41, S. 200, № 191]

Fig. 4. Cross-shaped buckles with a circular decor:

1 - Southern coast of Crimea, crypt 131 of Suuk-Su burial ground [23, fig. 108];

2 - Southwestern Crimea, crypt 257 Eski-Kermen [1, fig. 10, 8]; 3 - Asia Minor [41, S. 199, no. 189]; 4 - "Byzantium" [41, S. 200, no. 190]; 5 - Egypt, Achmom-Panopolis [41, S. 200, no. 191] 


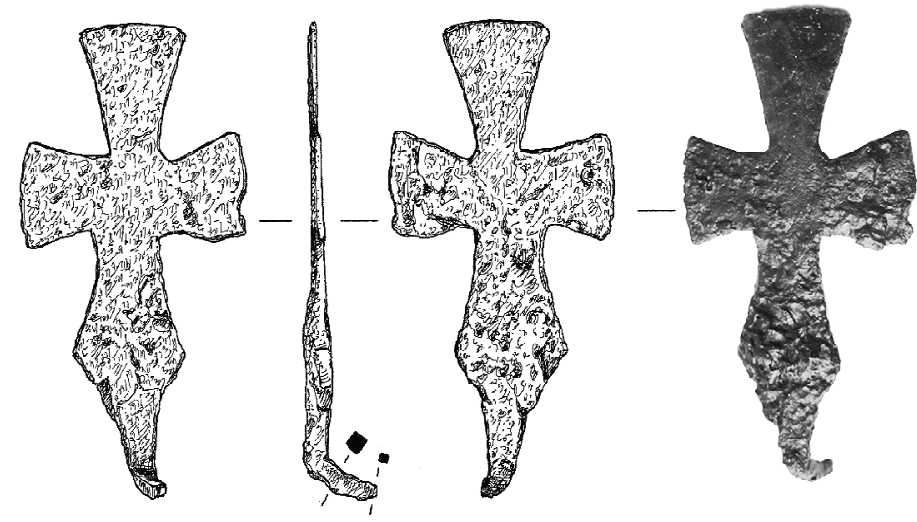

1

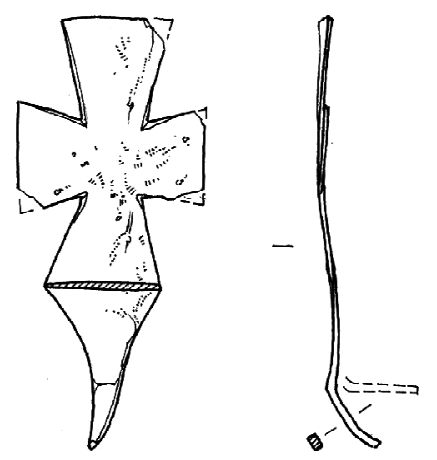

3

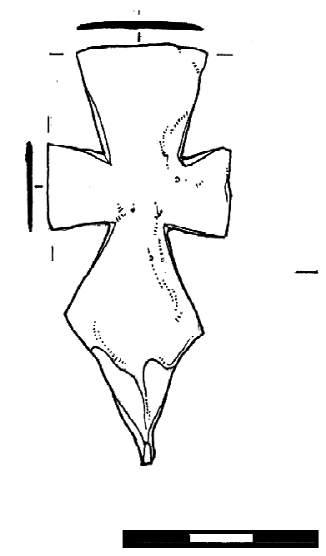

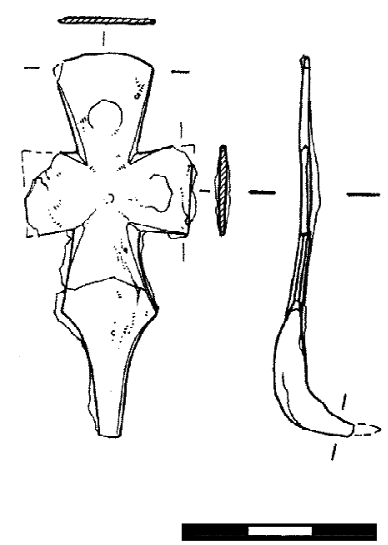

2

Рис. 5. Железные кресты с загнутой, удлиненной нижней ветвью:

1 - Южный берег Крыма, могильник Горзувиты, погребение 7А (рисунок и фото С.Л. Богаченко); 2 - Южный берег Крыма (Алушта), храм на холме Тузлух, с. Семидворье [20, рис. 5.5, 210]; 3, 4, 5 - Южный Крым, храм на горе Пахкал-Кая [14, рис. 5, 3, 4, 6]

Fig. 5. Iron crosses with a curved, elongated lower branch:

1 - Southern coast of Crimea, burial ground of Gorzuvity, burial 7A (drawing and photo by S.L. Bogachenko); 2 - Southern coast of Crimea, (Alushta), temple on Tuzlukh hill, Semidvorye village [20, fig. 5.5, 210];

3, 4, 5 - Southern Crimea, temple on Pakhkal-Kaya Mount [14, fig. 5, 3, 4, 6] 


\section{СПИСОК ЛИТЕРАТУРЫ}

1. Айбабин, А. И. Погребения конца VII - первой половины VIII в. в Крыму / А. И. Айбабин // Древности эпохи Великого переселения народов V-VIII вв. / отв. ред. А. К. Амброз, И. Ф. Эрдели. М. : Наука, 1982. - С. 165-192.

2. Армарчук, Е. А. Христианский храм у пос. Веселое: предварительная публикация результатов раскопок 2010 г. / Е. А. Армарчук, Р. А. Мимоход, Вл. В. Седов // Российская археология. -2012. № 3. - С. 78-90.

3. Беляев, Л. А. Византийский Иерихон: раскопки спустя столетие. Материалы Российско-Палестинской археологической экспедиции 20102013 гг. / Л. А. Беляев. - М. : ИА РАН; Индрик, 2016. $-500 \mathrm{c}$.

4. Василиненко, Д. Э. К вопросу о типологии и времени бытования железных крестов византийско-кавказского типа / Д. Э. Василиненко, А. В. Пьянков, М. А. Хушт // Православие в истории и культуре Северного Кавказа: вопросы источниковедения и историографии : материалы VII Международных Свято-Игнатьевских чтений. 2017. - Вып. І. - С. 14-29.

5. Веймарн, Е. В. Скалистинский могильник / Е. В. Веймарн, А. И. Айбабин. - Киев : Наукова Думка, 1993. - 203 с.

6. Дончева-Петкова, Л. Средновековни кръстове - енколпиони от България (IX-XIV в.) / Л. Дончева-Петкова. - София : Акад. изд. «Проф. Марин Дринов», 2011. - 752 c.

7. Завадская, И. А. Проблемы изучения кровельного материала средневековых центров ЮгоЗападного Крыма / И. А. Завадская // Труды Государственного Эрмитажа. T. LIII. Архитектура Византии и Древней Руси IX-XII веков : материалы Международного семинара, 17-21 ноября 2009 г. СПб. : Изд-во Гос. Эрмитажа, 2010. - С. 254-268.

8. Завадская, И. А. Проблемы интерпретации рельефных меток на средневековой черепице Крыма / И. А. Завадская // Материалы по археологии, истории и этнографии Таврии. - 2015. - Вып. XX. C. 213-232.

9. Завадская, И. А. Керамические комплексы хозяйственных вырубок в квартале 1 на городище Эски-Кермен (раскопки 2006 и 2007 гг.) / И. А. Завадская, Л. А. Голофаст // Материалы по археологии, истории и этнографии Таврии. - 2018. Вып. XXIII.-- С. 305-358.

10. Залесская, В. Н. Памятники византийского прикладного искусства IV-VII веков : каталог коллекции / В. Н. Залесская. - СПб. : Изд-во Гос. Эрмитажа, 2006. - 272 с.

11. Крупнов, Е. И. Христианский храм ХІІ в. на городище Верхний Джулат / Е. И. Крупнов // Средне- вековые памятники Северной Осетии : Труды Северо-Кавказской экспедиции 1958-1960 гг. Т. II. - М. : Изд-во Акад. наук СССР, 1963. - С. 48-65. - (Материалы и исследования по археологии СССР ; № 114).

12. Кузнецов, В. А. Христианство на Северном Кавказе до XV века / В. А. Кузнецов. - Владикавказ : Ир, 2002. - 159 с.

13. Ложкин, М. Н. Железные кресты византийско-кавказского типа из Отрадненского музея / М. Н. Ложкин, С. Н. Малахов // Историко-археологический альманах. - 1996. - Вып. 2. - С. 202-209.

14. Лысенко, А. В. Средневековый христианский храм на горе Пахкал-Кая в Южном Крыму / А. В. Лысенко, И. Б. Тесленко, А. Е. Мусин // В камне и бронзе / отв. ред. А. Е. Мусин. - СПб. : ИИМК РАН, ООО «Невская Книжная Типография», 2017. C. 291-310.

15. Майко, В. В. Средневековое городище на плато Тепсень в Юго-Восточном Крыму / В. В. Майко. - Киев : Академпериодика, 2004. - 316 с.

16. Майко, В. В. Средневековые некрополи Судакской долины / В. В. Майко. - Киев : Академпериодика, 2007. $-273 \mathrm{c}$.

17. Мастыкова, А.В. О погребальных конструкциях средневекового могильника Горзувиты / А. В. Мастыкова // Проблемы истории и археологии средневекового Крыма : материалы Междунар. науч. конф., посвящ. 70-летию А. И. Айбабина / ред.-сост. Э. А. Хайрединова. - Симферополь : Антиква, 2019. - С. 84-85, цв. вкл. 11, 12.

18. Мастыкова, А. В. Итоги исследования могильника Горзувиты в 2018 г. / А. В. Мастыкова // XX Боспорские чтения. Боспор Киммерийский и варварский мир в период античности и средневековья. Основные итоги и перспективы исследований : материалы Междунар. науч. конф. / ред.-сост. В. Н. Зинько, Е. А. Зинько. - Симферополь ; Керчь : ИР Кифниди Г.И., 2019. - С. 370-376.

19. Мастыкова, А. В. Предметы христианского культа из раннесредневекового некрополя Горзу-

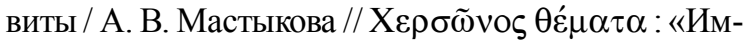
перия» и «Полис» : ХІ Международный Византийский семинар / отв. ред. Н. А. Алексеенко. - Симферополь : ИА Крыма РАН, 2019. - С. 155-158.

20. Мусин, А. Е. Металлические кресты / А. Е. Мусин // Археологический альманах. 2015. - № 32 : Древности Семидворья І. Средневековый двухапсидный храм в урочище Еди-Евлер (Алушта, Крым) : исследования и материалы / ред.-сост. И. Б. Тесленко, А. Е. Мусин-С. 189-218.

21. Пескова, А. А. Христианские древности Византии в «сирийской коллекции» Б.И. и В.Н. Ханенко / А. А. Пескова, Л. В. Строкова. - СПб. ; Киев : Петербургское Востоковедение, 2012. - 224 с.

22. Репников, Н. И. Некоторые могильники области крымских готов / Н. И. Репников // Известия 
императорской археологической комиссии. 1906. - Вып. 19. - С. 1-80.

23. Репников, Н. И. Некоторые могильники области крымских готов. Часть II / Н. И. Репников // Записки Одесского общества истории и древностей. - 1907. - Т. XXVII. - С. 101-148.

24. Тесленко, И. Б. «Средневековые крестовидные подвески из листового серебра» : Тридцать лет спустя / И. Б. Тесленко, А. Е. Мусин // Труды Государственного исторического музея. Вып. 198 : Славяне и иные языци... К юбилею Н.Г. Недошивиной / отв. ред. Н. И. Асташова. - М. : ГИМ, 2014. С. 242-253.

25. Тесленко, И. Б. Железные кресты средневековых памятников: «византийско-кавказские» или византийские? / И. Б. Тесленко, А. Е. Мусин // Археологическая наука: Практика, теория, история : сб. ст. памяти И.С. Каменецкого / отв. ред. А. Н. Гей, И. А. Сорокина. - М. : ИА РАН, 2016. - С. 204-219.

26. Хайрединова, Э. А. Раннесредневековые кресты из Юго-Западного Крыма / Э. А. Хайрединова // Материалы по археологии, истории и этнографии Таврии. - 2007. - Вып. ХІІІ. - С. 151-182.

27. Хайрединова, Э. А. Ожерелья с крестами последней четверти VI-VII вв. из некрополя ЭскиКермена / Э. А. Хайрединова // Владимирский сборник : материалы Международных научных конференций «І и II Свято-Владимирские чтения» / отв. ред. В. В. Майко, Т. Я. Яшаева. - Калининград : ИД «РОС-ДОАФК», 2016. -С. 280-299.

28. Якобсон, А. Л. Отчет об археологической разведке средневекового поселения и могильника Горзувит (близ Гурзуфа) в 1951 г. / А. Л. Якобсон // Архив ИА РАН. - Р-1. - 1951. - № 654.

29. Якобсон, А. Л. Разведочные раскопки средневекового поселения Горзувиты / А. Л. Якобсон // Краткие сообщения института истории материальной культуры. - 1954. - Вып. 53. - С. 109-120.

30. Якобсон, А. Л. Раннесредневековые сельские поселения Юго-Западной Таврики / А. Л. Якобсон. - Л. : Наука, 1970. - 224 с. - (Материалы и исследования по археологии СССР ; т. 168).

31. Bénazeth, D. L'art du métal au début de l'ère chrétienne/D. Bénazeth. - Paris : Editions de la Réunion des musées nationaux, 1992. - 303 p. - (Catalogue du département des antiquités égyptiennes).

32. Byzantine Hours, Works and Days in Byzantium : Everyday Life in Byzantium. Catalogue of Exhibition / ed. D. Papanikola-Bakartzi. - Athens : Hellenic Ministry of Culture, 2002. - 599 p.

33. Ferrazzoli, A. F. Byzantine Small Finds from Elaiussa Sebaste / A. F. Ferrazzoli // Byzantine Small Finds in Archaeological Contexts / ed. B. BohlendorfArslan, A. Ricci. - Istanbul : Ege Yayınları, 2012. P. 289-308. - (BYZAS : Veroffentlichungen des Deutschen Archäologischen Instituts ; Bd. 15).
34. Kazanski, M.M. Qal'at Sem'an. IV: Rapport final, 3: Les objets métalliques / M. M. Kazanski. Beyrout : Institut français du Proche-Orient, 2003.$162 \mathrm{p}$.

35. Magen, Y. The Northern Church at Beit'Anun / Y. Magen // Christians and Christianity. Vol. IV: Churches and Monasteries in Judea. (Judea \& Samaria Publications 16) / ed. N. Carmin. - Jerusalem : Israel Antiquities Authority, 2012. - P. 177-184.

36. Magen, Y., Peleg, Y., Sharukh, I. A Byzantine Church at 'Anab el-Kabir / Y. Magen, Y. Peleg, I. Sharukh // Christians and Christianity. Vol. IV: Churches and Monasteries in Judea. (Judea \& Samaria Publications 16) / ed. N. Carmin. - Jerusalem : Israel Antiquities Authority, 2012. - P. 331-384.

37. Orsi, P. Byzantine Siciliae / P. Orsi // Byzantinische Zeitschrift. - 1910. - Bd. 19. - P. 63-90.

38. Patrich, J. The Jewelry/J. Patrich, K. Rafael // Archaeological Excavations at Caesarea Maritima. Areas CC, KK and NN. Final report. Vol. 1: The Objects. - Jerusalem : Israel exploration society, 2008. P. 421-431.

39. Pieri, D. Saint-Syméon-le-Stylite (Syrie du Nord): les bâtiments d'accueil et les boutiques à l'entrée du sanctuaire / D. Pieri // Comptes rendus de séances de l'Académie des inscriptions et Belles-Lettres, $153^{\mathrm{e}}$ année. - 2009. - № 4.- P. 1393-1420.

40. Procopii Caesariensis Opera omnia libri IV. L. IV : De Aedificiis libri VI / eds. J. Haury, G. Wirth.Leipzig : Teubner, 1964. - xii, 408 p. - (Bibliotheca scriptorum graecorum et romanorum Teubneriana ; Vol. III-IV).

41. Schulze-Dörrlamm, M. Byzantinische Gürtelschnallen und Gürtelbeschläge im RömischGermanischen Zentralmuseum. Teil 1 : Die Schnallen ohne Beschläg des 5. bis 7. Jahrhunderts / M. SchulzeDörrlamm. - Mainz : Verl. des Römisch-Germanischen Zentralmuseums, 2002. $-262 \mathrm{p}$.

42. Vinski, Z. Kasnoantički starosjedioci u salonitanskoj regiji prema arheološkoj ostavštini predslavenskog supstrata / Z. Vinski // Vjesnik za arheologiju i historiju Dalmatinsku. LXIX. - Split : NITTP «Slobodna Dalmacija», 1974. - P. 5-87.

\section{REFERENCES}

1. Aybabin A.I. Pogrebeniya kontsa VII - pervoy poloviny VIII v. v Krymu [Burials of the Late $7^{\text {th }}-$ first half of the $8^{\text {th }}$ Century in Crimea]. Ambroz A.K., Erdeli I.F., eds. Drevnosti epokhi Velikogo pereseleniya narodov $V$-VIII vekov [Antiquities of the Great Migration Period of the $5^{\text {th }}-8^{\text {th }}$ Centuries]. Moscow, Nauka Publ., 1982, pp. 165-192.

2. Armarchuk E.A., Mimokhod R.A., Sedov V.V. Khristianskiy khram u pos. Veseloe: predvaritelnaya 
publikatsiya rezultatov raskopok 2010 g. [Christian Church near Veseloe Village. Preliminary Publication of 2010 Excavation Results]. Rossiyskaya arkheologiya [Russian Archaeology], 2018, vol. 3, pp. 78-90.

3. Belyaev L.A. Vizantiyskiy Ierikhon: raskopki spustya stoletie. Materialy Rossiysko-Palestinskoy arkheologicheskoy ekspeditsii 2010-2013 gg. [Byzantine Jericho: Excavations a Century Later. Materials of the Russian-Palestinian Archaeological Expedition of 2010-2013]. Moscow, IA RAN, Indrik Publ., 2016. 500 p.

4. Vasilinenko D.E., Pyankov A.V., Khusht M.A. $\mathrm{K}$ voprosu o tipologii i vremeni bytovaniya zheleznykh krestov vizantiysko-kavkazskogo tipa [On the Typology and Time of the Existence of the Iron Crosses of the Byzantine-Caucasian Type]. Pravoslavie $v$ istorii i kulture Severnogo Kavkaza: voprosy istochnikovedeniya i istoriografii: materialy VII Mezhdunarodnykh Svyato-Ignatyevskikh chteniy [Orthodoxy in the History and Culture of the North Caucasus: Issues of Source Study and Historiography. Materials of the $7^{\text {th }}$ International St. Ignatius Readings], 2017, vol. I, pp. 14-29.

5. Veymarn E.V., Aybabin, A.I. Skalistinskiy mogilnik [Skalistinsky Burial Ground]. Kiev, Naukova Dumka Publ., 1993. 203 p.

6. Doncheva-Petkova L. Srednovekovni krastove - enkolpioni ot Balgariya (IX-XIV v.) [Medieval Crosses - Encolpions from Bulgaria $\left(9^{\text {th }}-\right.$ $14^{\text {th }} \mathrm{c}$.)]. Sofiya, Akademichno izdatelstvo «Professora Marin Drinov», 2011. 752 p.

7. Zavadskaya I.A. Problemy izucheniya krovelnogo materiala srednevekovykh tsentrov YugoZapadnogo Kryma [Problems of Studying the Roofing Material of the Medieval Centers of Southwestern Crimea]. Trudy Gosudarstvennogo Ermitazha. T. LIII. Arkhitektura Vizantii i Drevney Rusi IX-XII vekov: materialy Mezhdunarodnogo seminara, 1721 noyabrya $2009 \mathrm{~g}$. [Proceedings of the State Hermitage. T. LIII. Architecture of Byzantium and Ancient Russia of the $9^{\text {th }}-12^{\text {th }}$ Centuries. Materials of the International Seminar, November 17-21, 2009]. Saint Petersburg, Izd-vo Gosudarstvennogo Ermitazha, 2010, pp. 254-268.

8. Zavadskaya I.A. Problemy interpretatsii relyefnykh metok na srednevekovoy cherepitse Kryma [The Problems of Interpretation of Relief Marks on Mediaeval Roof Tiles in Crimea]. Materialy po arkheologii, istorii i etnografii Tavrii [Materials in Archeology, History and Ethnography of Tauria], 2015, vol. XX, pp. 213-232.

9. Zavadskaya I.A, Golofast L.A. Keramicheskie kompleksy khozyaystvennykh vyrubok v kvartale 1 na gorodishche Eski-Kermen (raskopki 2006 i 2007 gg.) [Pottery Assemblages from Production Carvings in
Quarter 1 of the Ancient Town of Eski-Kermin (2006 and 2007 Excavations)]. Materialy po arkheologii, istorii i etnografii Tavrii [Materials in Archeology, History and Ethnography of Tauria], 2018, vol. XXIII, pp. 305-358.

10. Zalesskaya V.N. Pamyatniki vizantiyskogo prikladnogo iskusstva IV - VII vekov. Katalog kollektsii [Monuments of Byzantine Applied Art of the $4^{\text {th }}-7^{\text {th }}$ Centuries. Collection Catalog]. Saint Petersburg, Izd-vo Gosudarstvennogo Ermitazha, 2006. 272 p.

11. Krupnov E.I. Khristianskiy khram XII v. na gorodishche Verkhniy Dzhulat $\left[12^{\text {th }}\right.$ Century Christian Church on the Settlement of Upper Julat]. Srednevekovye pamyatniki Severnoy Osetii: Trudy Severo-Kavkazskoy ekspeditsii 1958-1960 gg., t. II). [Medieval Monuments of North Ossetia. Proceedings of the North Caucasian Expedition of 1958-1960, Vol. II. Moscow, Izd-vo Akademii nauk SSSR, 1963, pp. 48-65. (Materialy i issledovaniya po arkheologii SSSR [Materials and Research on Archaeology of the USSR], no. 114).

12. Kuznetsov V.A. Khristianstvo na Severnom Kavkaze do XV veka [Christianity in the North Caucasus Until the $15^{\text {s }}$ Century]. Vladikavkaz, Ir Publ., 2002. 159 p.

13. Lozhkin M.N., Malakhov S.N. Zheleznye kresty vizantiysko-kavkazskogo tipa iz Otradnenskogo muzeya [Iron Crosses of the Byzantine-Caucasian Type from the Otradnensky Museum]. Istorikoarkheologicheskiy almanakh [Historical and Archaeological Almanac], 1996, vol. 2, pp. 202-209.

14. Lysenko A.V., Teslenko I.B., Musin A.E. Srednevekovyy khristianskiy khram na gore РалhkalKaya v Yuzhnom Krymu [Medieval Christian Temple on the Pahkal-Kaya Mountain in Southern Crimea]. Musin A.E., ed. V kamne $i$ bronze [In Stone and Bronze]. Saint Petersburg, IIMK RAN, OOO «Nevskaya Knizhnaya Tipografiya», 2017, pp. 291-310.

15. Mayko V.V. Srednevekovoe gorodishche na plato Tepsen v Yugo-Vostochnom Krymu [Medieval Fortification on the Tepsen Plateau in Southeast Crimea]. Kiev, Akademperiodika Publ., 2004. 316 p.

16. Mayko V.V. Srednevekovye nekropoli Sudakskoy doliny [Medieval Necropolises of the Sudak Valley]. Kiev, Akademperiodika Publ., 2007. $273 \mathrm{p}$.

17. Mastykova A.V. O pogrebalnykh konstruktsiyakh srednevekovogo mogilnika Gorzuvity [Burial Structures in the Mediaeval Cemetery of Gorzubitai]. Khayredinova E.A., ed. Problemy istorii $i$ arkheologii srednevekovogo Kryma: materialy mezhdunarodnoy nauchnoy konferentsii, posvyashchennoy 70-letiyu A.I. Aybabina [Problems of the History and Archaeology of Medieval Crimea. Proceedings of the International Scientific Conference 
Dedicated to the $70^{\text {th }}$ Anniversary of A.I. Aybabin]. Simferopol, Antikva Publ., 2019, pp. 84-85.

18. Mastykova A.V. Itogi issledovaniya mogilnika Gorzuvity v 2018 g. [Results of the Study of the Gorzuvity Burial Ground in 2018]. Zinko V.N., Zinko E.A., eds. XX Bosporskie Chteniya. Bospor Kimmeriyskiy $i$ varvarskiy mir v period antichnost $i$ srednevekovya. Osnovnye itogi i perspektivy issledovaniy: materialy Mezhdunar. nauch. konf. [Cimmerian Bosporos and Barbarian World in the Period of Antiquity and Middle Ages. Main results and prospects of research. $20^{\text {th }}$ Bosporan Readings. Proceedings of the International Scientific Conference]. Simferopol, Kerch, IR Kifnidi G.I., 2019, pp. 370-376.

19. Mastykova A.V. Predmety khristianskogo kulta iz rannesrednevekovogo nekropolya Gorzuvity [Christian Cult Artefacts in the Early Mediaeval Cemetery of the Ancient Town of Gorzoubitai]. Alekseenko N.A., ed. Chersonos themata: "Imperiya" $i$ "Polis": XI Mezhdunarodnyy Vizantiyskiy seminar [Themes of Cherson: Empire and Polis. $11^{\text {th }}$ International Byzantine Seminar]. Simferopol, Institut Arkheologii Kryma RAN, 2019, pp. 155-158.

20. Musin A.E. Metallicheskie kresty [Metal Crosses]. Arkheologicheskiy almanakh. No. 32. Drevnosti Semidvorya I. Srednevekovyy dvukhapsidnyy khram $v$ urochishche Edi-Evler (Alushta, Krym): issledovaniya $i$ materialy [Archaeological Almanac. No. 32. Antiquities of the Semidvorye I. Medieval Two-Apse Temple in the EdiEvler Mountain Area (Alushta, Crimea). Research and Materials], 2015, pp. 189-218.

21. Peskova A.A., Strokova L.V. Khristianskie drevnosti Vizantii v «siriyskoy kollektsii» B.I. i V.N. Khanenko [The Christian Antiquities of Byzantium in the "Syrian Collection" of B.I. and V.N. Khanenko]. Saint Petersburg, Kiev, Peterburgskoe Vostokovedenie Publ., 2012. 224 p.

22. Repnikov N.I. Nekotorye mogilniki oblasti krymskikh gotov [Some Burial Grounds of the Area of Crimean Goths]. Izvestiya imperatorskoy arkheologicheskoy komissii, 1906, vol. 19, pp. 1-80.

23. Repnikov N.I. Nekotorye mogilniki oblasti krymskikh gotov. Chast II [Some Burial Grounds of the Area of Crimean Goths. Part II]. Zapiski Odesskogo obshchestva istorii i drevnostey, 1907, vol. XXVII, pp. 101-148.

24. Teslenko I.B., Musin A.E. "Srednevekovye krestovidnye podveski iz listovogo serebra": tridtsat let spustya [Medieval Silver Cross-Shaped Pendants: Thirty Years Later]. Astashova N.I., ed. Trudy Gosudarstvennogo istoricheskogo muzeya. Vyp. 198: Slavyane $i$ inye yazytsi... $K$ yubileyu N.G. Nedoshivinoy [Works of the State Historical Museum. Iss. 198. Slavs and Other Languages ... For the Anniversary of N.G. Nedoshivina]. Moscow, GIM Publ., 2014, pp. 242-253.

25. Teslenko I.B., Musin A.E. Zheleznye kresty srednevekovykh pamyatnikov: "vizantiyskokavkazskie» ili vizantiyskie? [Iron Crosses of Medieval Monuments: "Byzantine-Caucasian" or Byzantine?]. Gey A.N., Sorokina I.A., eds. Arkheologicheskaya nauka: Praktika, teoriya, istoriya: sb. st. pamyati I.S. Kamenetskogo [Archeological Science: Practice, Theory, History. Collection of Articles in Memory of I.S. Kamenetsky]. Moscow, IA RAN, 2016, pp. 204-219.

26. Khayredinova E.A. Rannesrednevekovye kresty iz Yugo-Zapadnogo Kryma [Early Medieval Crosses from the South-Western Crimea]. Materialy po arkheologii, istorii i etnografii Tavrii [Materials in Archeology, History and Ethnography of Tauria], 2007, iss. XIII, pp. 151-182.

27. Khayredinova, E.A. Ozherelya s krestami posledney chetverti VI-VII vv. iz nekropolya EskiKermena [Necklaces with Crosses of the Last Quarter of the $6^{\text {th }}-7^{\text {th }}$ Centuries from the Eski-Kermen Necropolis]. Mayko V.V., Yashaeva T.Ya., eds. Vladimirskiy sbornik: materialy Mezhdunarodnykh nauchnykh konferentsiy "I i II Svyato-Vladimirskie chteniya» [Vladimir Collection. Materials of the International Scientific Conferences " 1 st and $2^{\text {nd }}$ St. Vladimir Readings"]. Kaliningrad, ID "ROSDOAFK", 2016, pp. 280-299.

28. Yakobson A.L. Otchet ob arkheologicheskoy razvedke srednevekovogo poseleniya i mogilnika Gorzuvit (bliz Gurzufa) v 1951 g. [Report on the Archaeological Exploration of the Medieval Settlement and Gorzuvit Burial Ground (Near Gurzuf) in 1951]. Arkhiv Instituta arkheologii Rossiyskoy akademii nauk [Archive of the Institute of Archaeology of the Russian Academy of Sciences], R-1, 1951, no. 654.

29. Yakobson A.L. Razvedochnye raskopki srednevekovogo poseleniya Gorzuvity [Exploration Excavations of Gorzuvity Medieval Settlement]. Kratkie soobshcheniya instituta istorii materialnoy kultury, 1954, vol. 53, pp. 109-120.

30. Yakobson A.L. Rannesrednevekovye selskie poseleniya Yugo-Zapadnoy Tavriki [Early Medieval Rural Settlements of the Southwestern Taurica]. (Materialy i issledovaniya po arkheologii SSSR) [Materials and Research on Archaeology of the USSR]. Leningrad, Nauka Publ., 1970, vol. 168. 224 p.

31. Bénazeth D. L'art du métal au début de l'ère chrétienne. Paris, Editions de la Réunion des musées nationaux, 1992. 303 p. (Catalogue du département des antiquités égyptiennes).

32. Papanikola-Bakartzi D., ed. Byzantine Hours, Works and Days in Byzantium: Everyday Life in Byzantium. Catalogue of Exhibition. Athens, Hellenic Ministry of Culture, $2002.599 \mathrm{p}$. 


\section{ВИЗАНТИЙСКАЯ ТАВРИКА}

33. Ferrazzoli A.F. Byzantine Small Finds from Elaiussa Sebaste. Bohlendorf-Arslan B., Ricci A., eds. Byzantine Small Finds in Archaeological Contexts. Istanbul, Ege Yaylnlarl, 2012, pp. 289-307. (Byzas: Veroffentlichungen des Deutschen Archäologischen Instituts; Bd. 15).

34. Kazanski M.M. Qal'at Sem'an. IV: Rapport final. 3: Les objets métalliques. Beyrouth, Institut français du Proche-Orient, 2003. 162 p.

35. Magen, Y. The Northern Church at Beit' Anun. Carmin N., ed. Christians and Christianity. Vol. IV: Churches and Monasteries in Judea. (Judea \& Samaria Publications 16). Jerusalem, Israel Antiquities Authority, 2012, pp. 177-184.

36. Magen Y., Peleg Y., Sharukh I. A Byzantine Church at 'Anabel-Kabir. Carmin N., ed. Christians and Christianity. Vol. IV: Churches and Monasteries in Judea. (Judea \& Samaria Publications 16). Jerusalem, Israel Antiquities Authority, 2012, pp. 331-384.

37. Orsi P. Byzantine Siciliae. Byzantinische Zeitschrift, 1910, Bd. 19, pp. 63-90.

38. Patrich J., Rafael K. The Jewelry. Archaeological Excavations at Caesarea Maritima.
Areas CC, KK and NN. Final report. Vol. 1: The Objects. Jerusalem, Israel Exploration Society, 2008, pp. 421-431.

39. Pieri D. Saint-Syméon-le-Stylite (Syrie du Nord): les bâtiments d'accueil et les boutiques à l'entrée $\mathrm{du}$ sanctuaire. Comptes rendus de séances de l'Académie des inscriptions et Belles-Lettres, $153^{e}$ année, 2009, № 4, pp. 1393-1420.

40. Haury J., Wirth G., eds. Procopii Caesariensis Opera omnia libri IV. L. IV: De Aedificiis libri VI. Leipzig, Teubner, 1964. Xii, 408 p. (Bibliotheca scriptorum graecorum et romanorum Teubneriana; Vol. III-IV).

41. Schulze-Dörrlamm M. Byzantinische Gürtelschnallen und Gürtelbeschläge im RömischGermanischen Zentralmuseum. Teil 1: Die Schnallen ohne Beschläg des 5. bis 7. Jahrhunderts. Mainz, Verl. des Römisch-Germanischen Zentralmuseums, 2002.262p.

42. Vinski Z. Kasnoantički starosjedioci u salonitanskoj regiji prema arheološkoj ostavštini predslavenskog supstrata. Vjesnik za arheologiju $i$ historiju Dalmatinsku. LXIX. Split, NITTP "Slobodna Dalmacija", 1974, pp. 5-87.

\section{Information about the Author}

Anna V. Mastykova, Doctor of Sciences (History), Leading Researcher, Institute of Archaeology of the Russian Academy of Sciences, Dm. Ulyanova St., 19, 117292 Moscow, Russian Federation, amastykova@mail.ru,https://orcid.org/0000-0001-7521-5071

\section{Информация об авторе}

Анна Владимировна Мастыкова, доктор исторических наук, ведущий научный сотрудник, Институт археологии РАН, ул. Дм. Ульянова, 19, 117292 г. Москва, Российская Федерация, amastykova@mail.ru, https://orcid.org/0000-0001-7521-5071 